Vol. 19 (2010): 252-268.

\title{
Development of yield and nutritive value of timothy in primary growth and regrowth in northern growing conditions
}

\author{
Oiva Nissinen ${ }^{1,3^{*}}$, Pekka Kalliainen ${ }^{1}$ and Lauri Jauhiainen ${ }^{2}$ \\ ${ }^{1}$ MTT Agrifood Research Finland, Plant Production Research, Eteläranta 55, FI-96300 Rovaniemi, Finland \\ *e-mail: oiva.nissinen@pp.inet.fi \\ ${ }^{2}$ MTT Agrifood Research Finland, Services Unit, FI-31600 Jokioinen, Finland \\ ${ }^{3}$ Present address: Hakkurintie 7, FI-96460 Rovaniemi, Finland
}

The development of the yield and nutritive value of timothy (Phleum pratense L.) both in the primary growth and in the regrowth were studied at MTT Plant Production Research, a unit of MTT Agrifood Research Finland, in Rovaniemi $\left(66^{\circ} 35^{\prime} \mathrm{N}\right)$ in $1999-2001$. The dry matter yield and leaf to stem ratio were measured from the crop samples, and the contents of crude protein and organic matter digestibility of both whole plant samples and leaf and stem fractions were analysed. In primary growth, the most rapid increase of dry matter, $220-240 \mathrm{~kg} \mathrm{ha}^{-1}$ per day, was measured around the beginning of the heading stage. There was a very strong positive correlation between the proportion of stems and the amount of dry matter in the primary yield. The daily growth rate of the regrowth was less than half of that of the primary growth. The fastest decrease, 1 percentage unit per day, in crude protein content was measured at the pasture stage (4-5-leaf stage). During the entire sampling period, the average daily decline in crude protein content in the primary growth of timothy was 0.65 percentage units. The main cause for the rapid decline in crude protein content was the high proportion of stems and their low protein content. In the regrowth, during the last four weeks before the harvest, the average daily decline in crude protein content was 0.28 percentage units. The average decline in organic matter digestibility from early pasture stage to late silage stage was 0.9 percentage units per day. The most remarkable change was noticed at the growth stage of timothy when about the half of stems were heading and it was then that the digestibility decreased by more than one percentage unit per day. The rapid decline in organic matter digestibility was due to the low digestibility of stem matter. The daily change in forage digestibility in the regrowth was very small, on average $0.11 \%$.

Key-words: Phleum pratense, timothy, dry matter yield, leaf to stem ratio, organic matter digestibility, crude protein content 
Vol. 19(2010): 252-268.

\section{Introduction}

In Northern Finland, nearly $80 \%$ of the cultivated area is used for growing perennial grassland plants, and grass forage accounts for nearly $60 \%$ of the feed units used per milk cow (Ministry of Agriculture and Forestry 2008). Timothy is the most widely cultivated ley crop in Finnish Lapland, where it comprises over $90 \%$ of the seed used to establish leys (Nissinen 1998). The mean temperatures in Northern Finland, too, are high enough for the growth of grass species such as timothy and meadow fescue (Pulli 1989), but the shortness of the growing season reduces the number of cuts and thereby the amounts of the total yields. Close to the Arctic Circle, the growing period (when the mean daily temperature exceed $+5^{\circ} \mathrm{C}$ ) begins $1-2$ weeks after melting of the snow in the middle of May and averages 139 days and $879{ }^{\circ} \mathrm{C}$ effective day-degrees (base +5 ${ }^{\circ} \mathrm{C}$ ) ( measured in MTT Rovaniemi in 1971-2000). However, only about 100 days can be exploited for yield production because the sward requires the last third of the growing period and the last quarter of the temperature sum to accumulate reserve nutrition and to attain winter hardiness.

After a late growth start, the northern timothy swards exhibit a fast growth rate and a rapid change in nutritive value (Thorvaldsson and Andersson 1986). Consequently, the correct timing of the first harvest is very important as regards the quantity of the primary yield in northern growing conditions. However, when timothy is cut twice for silage, the average proportion of the second yield has been more than 40\% (Nissinen and Hakkola 1994, Nissinen 1998). In many years, winter damage to timothy leys caused by snow moulds decreases the yield of the first cuts and increases the proportion of the regrowth in the total yields. This emphasizes the economic importance of the amount and quality of the regrowth as regards the total feed harvested during the short northern growing season (Nissinen and Hakkola 1995, Rinne 2000). In Northern Finland, due to overwintering injuries and the diminished yield potential of timothy with ageing of the swards, timothy leys are established with an eye to 3-4 productive years. Young timothy swards exhibit a great growth in early summer and that results in a high increase in yield and also in rapid changes in nutritive value. In the study by Belanger et al. (2008), it was found that the greater dry matter yield of younger swards was not due to differences in air temperature in the weeks preceding stem elongation.

In practice, heading is the only visible sign in timothy indicating the time for the first harvest. According to Gustavsson and Martinsson (2004), the development of heads is not a good indicator of the quality factors between different years and between different cuts because plant development does not indicate the optimum value of digestibility or growth.

According to Thorvaldsson (1988), the protein content of the spring harvest is higher than that of the second harvest at the same morphological stage of development. The aftermath has more time to grow and the amount of the yield with respect to the stage of development is higher than in the spring harvest, which reduces the protein content.

High organic matter digestibility is the most important qualitative criterion for grass forage. According to the literature reviewed by Rinne (2000) the average dry matter intake and milk yield responses were 0.16 and $0.32 \mathrm{~kg} /$ day per 10 $\mathrm{g}$ increase in silage's D-value (digestible organic matter, g kg-1 DM). In the study by Kuoppala et al. (2008), the milk production of dairy cows reflected the intake of metabolizable energy and no differences in the utilization of this energy were found between silages harvested from primary growth and regrowth.

Many experiments have shown a faster decline in digestibility at more northerly latitudes (Deinum et al. 1981). This may be due to faster stem development and lower leaf dry matter production at northern latitudes. However, Deinum et al. (1981) observed also that, at the same morphological stage of development, organic matter digestibility is higher at northern latitudes than it is at southern latitudes. The low temperature has the effect of decreasing the crude fibre content of the dry matter. According to Bertrand et al. (2008), the higher dry matter digestibility of timothy grown under cool temperatures was caused by an increase in cell wall 
Nissinen, O. et al. Dry matter yield and nutritive value of timothy

digestibility, in part due to the delay in reaching a given stage of development under cooler temperature. The different development of regrowth digestibility compared to that of primary growth may be caused by the lower growing temperatures having a retarding impact on lignin synthesis (Van Soest et al. 1978) and the proportion of leaves in the total herbage mass not declining with the advance in grass growth during late summer ( $\AA$ man and Lindgren 1983, Rinne et al. 2000).

Under the cool and short northern growing season, non-limiting nutrient conditions are important in order to ensure abundant grass growth. Dry matter yield and crude protein content increase with increase in nitrogen application. However, as reviewed by Thorvaldsson (2006), the effect of nitrogen fertilization on digestibility has been minor and variable. In Northern Sweden, increase in nitrogen application has resulted in a faster decline in digestibility, and the effect has been greater on the second crop (Thorvaldsson and Andersson 1986). It has also been found that late fertilization in spring reduces the decline in digestibility (Björnsson and Hermansson 1983 ref. Thorvaldsson 2006). In Rovaniemi, the timing of nitrogen fertilization around the actual beginning of growth at the end of May has increased the crude protein content in the silage yield of the first cut, while nitrogen fertilization before the onset of visible green growth has resulted in a low protein content, but without reducing the dry matter yield (MTT Rovaniemi, trial results in 1985-1990, unpublished).

The main objective of the present field experiment was to define the increase in yield and the decline in crude protein content and forage digestibility at different stages of maturity both in the primary growth and in the regrowth of timothy. Two levels of nitrogen fertilization were used in accordance with the farming practices of Northern Finland. Further objectives were to reveal those factors in forage management that are involved in the rapid decline of the nutritive value of forage and to demonstrate the necessity to optimise the date of harvesting with respect to yield amounts and nutritive values. From the practical point of view, the harvesting strategy concerning the benefit of grass growth in general during the short northern growing season is also discussed.

\section{Materials and methods}

The present investigation is based on field trials carried out at MTT Plant Production Research, a unit of MTT Agrifood Research Finland, in Rovaniemi $\left(66^{\circ} 35^{\prime} \mathrm{N}\right)$ in $1999-2001$. The study consisted of first to third year timothy (Phleum pratense L., $c v$. Iki) stands established in 1998.

The experiment was established applying a seeding rate of 4000 seeds $/ \mathrm{m}^{2}\left(20 \mathrm{~kg} \mathrm{ha}^{-1}\right)$. The size of the experimental plot was $12 \mathrm{~m}^{2}(8 \times 1.5$ $\mathrm{m})$. The underlying soil was silty fine sand, $\mathrm{pH}$ 6.6, Ca 1430, K 99, P 24, and Mg $405 \mathrm{mg} \mathrm{l}^{-1}$. The plots received annually fertilization at the rates of 160-200 kg N, 16-20 kg P, and 96-120 kg K per hectare in the form of a compound fertilizer. The choice of compound fertilizer and the application of nutrients were based on soil analyses and the optimum fertilization rates for yield formation. The differences between the amounts of $\mathrm{P}$ and $\mathrm{K}$ are not of limitation for growth and nutritive value. The field experiment was set-up according to the splitplot experimental design with three replicates. Two levels of nitrogen fertilization, 80 and $100 \mathrm{~kg} \mathrm{ha}^{-1}$ given for both the primary yields and the regrowth were the main plot factors. Five different timings for primary growth harvest and three cutting dates for regrowth were the subplot factors. The experimental treatments, i.e. harvesting regimes, maturity stages and harvesting dates for the primary growth and the regrowth are shown in Table 1.

Overwintering of the timothy stands was determined visually in the spring just after snow melt by observing the cause of winter injuries (lowtemperature fungi, abiotic factors) and by estimating the proportion of dead swards applying a scale of $0-100 \%$. Winter damage was evaluated on the basis of the ground cover percentage ( $0-100 \%$ of sown plants) of the plot in the autumn and in the spring. The final estimates of stand density in the spring and, based on these, the determining of win- 
Vol. 19(2010): 252-268.

ter damage, were made later on after the start of growth applying a scale of $0-100 \%$.

To facilitate timing of each harvest, the stage of development of timothy was observed visually, and five maturity stages were defined for the primary growth and three for the regrowth.

The swards were harvested using a forage plot harvester (Haldrup) set to cut at a height of about $5 \mathrm{~cm}$ above ground level. Before each harvest, the total heights of the stands were measured on three randomly chosen spots per plot to extended leaf tips / top of heads. The fresh yields were weighed and herbage samples of $2000 \mathrm{~g}$ were taken for quality analyses and for separating yield components. Representative samples of approximately $1 \mathrm{~kg}$ were weighed to determine the botanical composition. The amount of timothy and unsown species were determined, and the proportion of timothy plants was fractionated into leaves and stems. The main part of the leaf sheaths was included in the stem fraction. Both the whole plant samples and the different fractions (leaves and stems) were analysed for dry matter $(\%)$, ash $(\%)$, nitrogen $(\mathrm{N}, \%)$, crude fibre $(\%)$ and organic matter digestibility (\%). The crude protein content was calculated as $6.25 \times \mathrm{N}$. The samples were dried, first for two hours at 100 ${ }^{\circ} \mathrm{C}$ and then at $60{ }^{\circ} \mathrm{C}$ until dry. The dried samples were ground by means of a mill (Sakomylly, Finland) through a sieve with $1 \mathrm{~mm}$ pore size. Kjeldahl nitrogen was determined with the standard Kjeldahl method number 984.13 (AOAC 1990) using $\mathrm{Cu}$ as the digestion catalyst and Gerhardt Vapodest Distillig Unit (Gerhardt, Germany). The crude fibre content was determined using the Fibertec system (Tecator, Sweden). The digestibility of the organic matter was tested in vitro by using the cellulaseenzyme method of Friedel (1990) and Onozuka R-10 (Yakult Honsha Co. Ltd, Tokyo, Japan) cellulase. The ash content was determined by placing sample material in a muffle furnace at $600^{\circ} \mathrm{C}$ for at least 4 hours. The climatological data are based on the measurements carried out at MTT Rovaniemi (Apukka), which is one of the official weather ob-

Table 1. Experimental treatments in 1999-2001.

\begin{tabular}{|c|c|c|c|c|c|}
\hline \multirow{2}{*}{\multicolumn{6}{|c|}{ A. Nitrogen (N) fertilization, $\mathrm{kg} \mathrm{ha}^{-1}$}} \\
\hline & & & & & \\
\hline \multicolumn{6}{|c|}{ 1. $(80 \mathrm{~N}) 80+80$ (primary growth + regrowth) } \\
\hline \multicolumn{6}{|c|}{ 2. $(100 \mathrm{~N}) 100+100$ (primary growth + regrowth) } \\
\hline \multicolumn{6}{|c|}{ B. Harvesting regime / stage of development for primary growth / cutting date } \\
\hline \multicolumn{6}{|l|}{ Cut 1 . } \\
\hline 1. Early pasture stage (EP) & 4 leaf stage & 17.6. & 13.6. & 13.6. & 14.6 \\
\hline 2. Late pasture stage (LP) & 5 leaf stage & 21.6. & 15.6. & 19.6. & 18.6. \\
\hline 3. Early silage stage (ES) & first heads are visible & 23.6. & 26.6 & 21.6. & 23.6. \\
\hline 4. Silage stage (S) & $30-60 \%$ of the stems are heading & 28.6. & 29.6 & 26.6 . & 28.6. \\
\hline 5. Late silage stage (LS) & $70-100 \%$ of the stems are heading & 1.7. & 6.7. & 2.7. & 3.7. \\
\hline \multicolumn{6}{|c|}{ C. Harvesting regime for regrowth / cutting dates } \\
\hline \multicolumn{6}{|l|}{ Cut 1: } \\
\hline For all treatments at silag & & 28.6. & 29.6 & 26.6 . & 28.6. \\
\hline \multicolumn{6}{|l|}{ Cut 2 . } \\
\hline 1. (4W) 4 weeks after the fi & & 27.7. & 25.7 & 25.7 & 26.7. \\
\hline 2. $(6 \mathrm{~W}) 6$ weeks after the fi & & 9.8. & 9.8. & 9.8. & 9.8. \\
\hline 3. $(8 \mathrm{~W}) 8$ weeks after the fi & & 24.8 . & 24.8 & 23.8. & 24.8 \\
\hline
\end{tabular}


Nissinen, O. et al. Dry matter yield and nutritive value of timothy

servation stations of the Finnish Meteorological Institute.

Statistical analysis based on the applied experimental design. First and second cut were analysed separately. In addition, repeated measurements were taken from all plots and the following model takes into account the fact that repeated measurements can be correlated:

$\mathrm{y}_{\mathrm{ijkl}}=\mu+\mathrm{B}_{1}+\mathrm{N}_{\mathrm{i}}+\mathrm{BN}_{\mathrm{il}}+\mathrm{C}_{\mathrm{j}}+\mathrm{NC}_{\mathrm{ij}}+\mathrm{Y}_{\mathrm{k}}+\mathrm{YB}_{\mathrm{kl}}+$ $\mathrm{YN}_{\mathrm{ki}}+\mathrm{YBN}_{\mathrm{kil}}+\mathrm{YC}_{\mathrm{kj}}+\mathrm{YNC}_{\mathrm{kij}}+\varepsilon_{\mathrm{ijkl}}$

where $\mu$ is the intercept, $\mathrm{N}_{\mathrm{i}}, \mathrm{C}_{\mathrm{j}}$ and $\mathrm{NC}_{\mathrm{ij}}$ are the fixed effects of nitrogen fertilization ( $\mathrm{i}=80$ or 100 $\left.\mathrm{kg} \mathrm{ha}^{-1}\right)$, cutting dates $(\mathrm{j}=1, \ldots, 5)$, and their interaction, respectively. $\mathrm{B}_{1}$ and $\mathrm{BN}_{\mathrm{il}}$ are the random effects of block $(1=1, \ldots, 3)$ and the main plot error. The model assumes that the random effects are mutually independent and normally distributed with zero means and variances of $\sigma_{B}^{2}$ and $\sigma_{B N}^{2}$. This part of the model is identical to that used for the standard split-plot experiments. The rest of the model includes effects related to the within-plot variation. $\mathrm{Y}_{\mathrm{k}}, \mathrm{YN}_{\mathrm{ki}}, \mathrm{YC}_{\mathrm{kj}}$ and $\mathrm{YNC}_{\mathrm{kij}}$ are the fixed effects of the year $(k=1999,2000$ or 2001), year $\times$ nitrogen fertilization, year $\times$ cutting dates, and year $\times$ nitrogen fertilization $\times$ cutting dates interactions, respectively. $\mathrm{YB}_{\mathrm{kl}}$ and $\mathrm{YBN}_{\mathrm{kil}}$ are the random effects for year $\times$ block and year $\times$ block $\times$ nitrogen fertilization interaction, respectively. The model assumes that the random effects are mutually independent. $\varepsilon_{\mathrm{ijk} l}$ are the correlated residuals i.e. the residuals from the same plot are correlated but the residuals from different plots are not. The covariance-variance matrix, which modelled the correlation between the repeated measurements, was Heterogeneous Compound Symmetry (CSH) in all analyses. The $\mathrm{CSH}$ allows that the random variation can vary from year to year but the correlations between the years are constant. Statistical analyses were carried out by running the SAS/MIXED program using the REML-estimation method. The distribution of organic matter digestibility was skew. To avoid statistical problems arising from skewness, an arc sin-transformation was done. All estimates obtained from the statistical analysis were transformed to the original scale. However, as it is not possible to transform standard errors to the original scale, the standard errors for the estimates of organic matter digestibility are not presented.

The correlation analysis was performed to measure the relationships between the studied traits. The analysis was performed by running the SAS/CORR program. The correlation analysis has some problems: age of ley has only a few levels and the weather variables are not independent between the observations. This means that the serious consideration must to make before drawing conclusions. Many of the correlation found are clear and systematic and therefore the results are mostly adequate. For example, interaction between the year and the cutting dates were found in several analyses. The order of the levels of the cutting dates was same in each year, but the difference varied from year to year. This means, that the statistically significant interaction was not always practically important and weather parameters were one of the major phenomena behind the found interaction.

Statistical signifcances for main effects of nitrogen fertilization, cutting time, year and their interactions were presented in Table 7. Most of the statistically significant effects were not important, e.g. several differences were found between years. The most important effects were examined in the next chapters.

\section{Results}

\section{Dry matter yields}

The average winter damage between the treatments varied from $7 \%$ to $20 \%(\mathrm{SE}=2.7 \%)$ and the differences were statistically significant $(p=0.02)$. The principal cause of damages was speckled snow mould (Typhula sp.). There was more damage in the swards harvested at about the beginning of heading in the previous years. In the trial, timothy suffered the least winter damage when cut at the late silage stage. For the most part, winter injuries in the 
Vol. 19(2010): 252-268.

second- and third-year leys were restricted to the foliage of timothy. However, there was a statistically significant correlation between the highest degree of winter damage and low yields $(r=-0.31, p<$ 0.01 ). Also early cut and the higher rate of nitrogen fertilization applied to the regrowth caused poorer overwintering due to the increased incidence of pink snow mould (Microdochium nivale) and speckled snow mould (Typhula sp.) in the swards.

When the present study was being conducted, the growing season (mean daily temperature above $+5{ }^{\circ} \mathrm{C}$ ) began, on average, on 15 May. The period from the beginning of the growing season to the date of first visible heads, 23 June, averaged 39 days and the accumulated average effective temperature sum was $221^{\circ} \mathrm{C}$ (Table 2). At that growth stage, the dry matter yield of timothy was about $3100 \mathrm{~kg} \mathrm{ha}^{-1}$. During the following ten days from the point in time of the first visible heads to full heading the yield increased by $2000 \mathrm{~kg} \mathrm{ha}^{-1}$, the sum of the effective day degrees increased by 115 ${ }^{\circ} \mathrm{C}$, and the proportion of leaves in the yield was reduced to $25 \%$.
The dry matter yields of timothy were measured from the early pasture stage (4-leaf stage, plant height $30-40 \mathrm{~cm}$ ) to the late silage stage when $70-100 \%$ of the stems were heading. During this developmental period, the average yield increase at lower $(80 \mathrm{~N})$ and higher $(100 \mathrm{~N})$ nitrogen levels was from 1210 to 5210 and from 1340 to $5030 \mathrm{~kg}$ $\mathrm{ha}^{-1}\left(\mathrm{se}=138 \mathrm{~kg} \mathrm{ha}^{-1}\right)$, respectively (Table 3$)$. These increases were statistically significant $(p<0.001)$, but the difference between the nitrogen levels was not statistically significant $(p=0.91)$. The interaction of nitrogen fertilization $\times$ cutting date was also not statistically significant $(p=0.68)$. The most rapid increase in dry matter, $220-240 \mathrm{~kg} \mathrm{ha}^{-1}$ in a day $\left(S E=22.1 \mathrm{~kg} \mathrm{ha}^{-1}\right)$, was measured around the beginning of the heading stage (Table 3 ). At that point in time, the timothy plants shot up, on average, by $3 \mathrm{~cm}(S E=0.2 \mathrm{~cm})$ in a day. Within a period of ten days from the first visible heads to full heading, the dry matter yield increase averaged 2000 $\mathrm{kg} \mathrm{ha}^{-1}\left(S E=116 \mathrm{~kg} \mathrm{ha}^{-1}, p<0.001\right)$. The higher amount of nitrogen accelerated the early growth of timothy, but the differences in dry matter levelled

Table 2. Accumulation of effective growing day-degrees (GDD) and precipitation for each harvest of primary yield and aftermath in 1999-2001.

\begin{tabular}{|c|c|c|c|c|c|c|c|c|c|}
\hline \multirow{2}{*}{\multicolumn{2}{|c|}{$\begin{array}{l}\text { Treatment/ } \\
\text { cutting date }\end{array}$}} & \multicolumn{3}{|c|}{$\mathrm{GDD},{ }^{\circ} \mathrm{C}$} & \multirow[b]{2}{*}{ Mean } & \multicolumn{3}{|c|}{ Precipitation, mm } & \multirow[b]{2}{*}{ Mean } \\
\hline & & 1999 & 2000 & 2001 & & 1999 & 2000 & 2001 & \\
\hline \multicolumn{10}{|c|}{ Primary growth: } \\
\hline EP & 14.6. & 181 & 169 & 95 & 148 & 54 & 67 & 71 & 64 \\
\hline LP & 18.6. & $218(+37)$ & $178(+9)$ & $153(+58)$ & $183(+35)$ & 69 & 86 & 93 & 82 \\
\hline ES & 23.6 . & $242(+24)$ & $245(+67)$ & $176(+23)$ & $221(+38)$ & 72 & 102 & 93 & 89 \\
\hline S & 28.6 . & $309(+67)$ & $284(+39)$ & $236(+60)$ & $276(+55)$ & 73 & 113 & 93 & 93 \\
\hline LS & 3.7. & $354(+45)$ & $353(+69)$ & $302(+66)$ & $336(+60)$ & 73 & 123 & 100 & 98 \\
\hline \multicolumn{10}{|c|}{ Regrowth: } \\
\hline $4 W$ & 26.7 & 324 & 295 & 326 & 315 & 130 & 74 & 99 & 101 \\
\hline $6 \mathrm{~W}$ & 9.8. & $408(+84)$ & $447(+152)$ & $445(+119)$ & $433(+118)$ & 148 & 82 & 136 & 122 \\
\hline $8 \mathrm{~W}$ & 24.8 . & $477(+69)$ & $547(+100)$ & $559(+114)$ & $528(+95)$ & 156 & 113 & 173 & 147 \\
\hline
\end{tabular}

Stages of growth: EP - early pasture, LP - late pasture, ES - early silage, S - silage, LS - late silage, $4 \mathrm{~W}$ - 4 weeks after the first cut, $6 \mathrm{~W}$ - 6 weeks after the first cut, 8W - 8 weeks after the first cut. ( ) - increase in GDD between cutting dates. 
Nissinen, O. et al. Dry matter yield and nutritive value of timothy

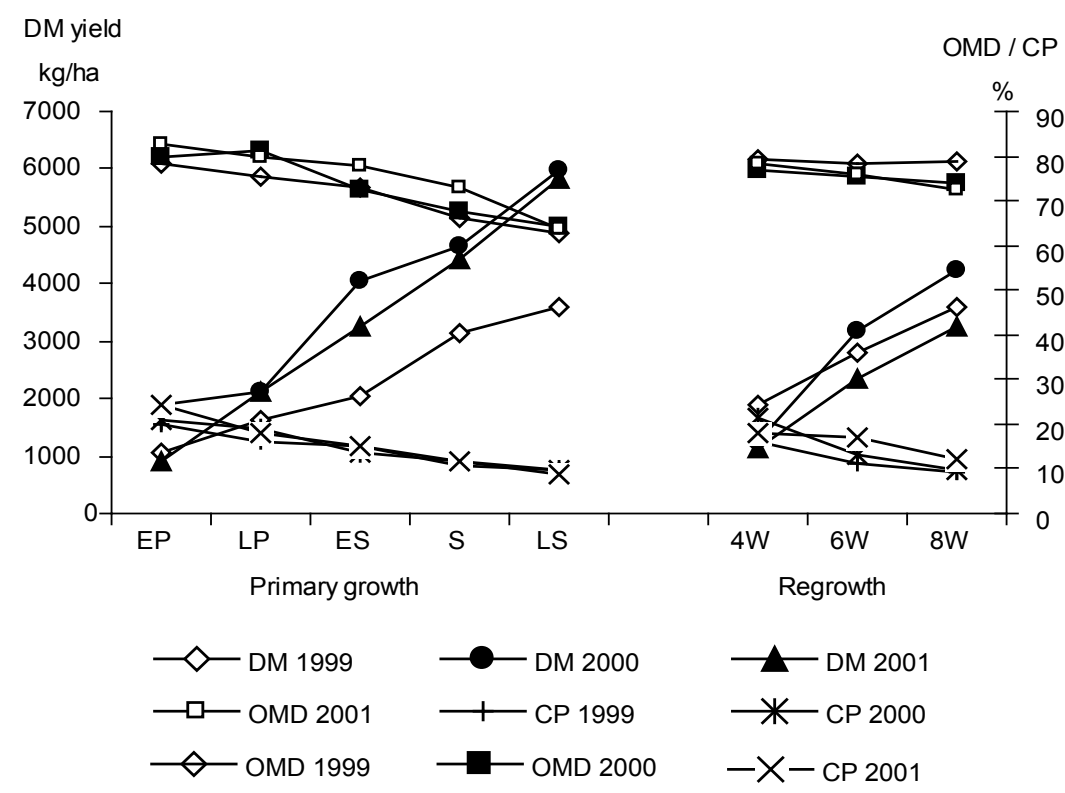

Fig. 1. Dry matter yield (DM), crude protein content (CP) and organic matter digestibility (OMD) of timothy at different maturity stages in primary growth and regrowth in different trial years. Levels of nitrogen fertilization are combined. Stages of growth: EP - early pasture, LP - late pasture, ES - early silage, S - silage, LS - late silage, $4 \mathrm{~W}$ - 4 weeks after the first cut, $6 \mathrm{~W}-6$ weeks after the first cut, $8 \mathrm{~W}-8$ weeks after the first cut, DM - dry matter, $\mathrm{kg} / \mathrm{ha}, \mathrm{CP}$ - crude protein content, $\%$ in DM, OMD - organic matter digestibility, $\%$.

off by the time of the silage stage. There was a great variation between the trial years in regard to the amount of dry matter at different maturity stages of primary growth (Fig.1). Also the response of the dry matter yield to the accumulated effective day-degrees varied from year to year.

The daily growth rate of the regrowth was less than half of that of the primary yield, i.e. about 80 $\mathrm{kg} \mathrm{ha}^{-1}\left(S E=12 \mathrm{~kg} \mathrm{ha}^{-1}\right)$ in a day. Between four and six weeks after the first cut done at the silage stage, the daily increase of dry matter was at its highest, i.e. $80-110 \mathrm{~kg} \mathrm{ha}^{-1}$, but during the following last period of two weeks in August the increase was only about $60 \mathrm{~kg}$. During those four weeks, the amount of dry matter in the swards increased from $1400-1430$ to $3540-3850 \mathrm{~kg} \mathrm{ha}^{-1}\left(S E=211 \mathrm{~kg} \mathrm{ha}^{-1}\right.$, $p<0.001$ ) with fertilization doses being 80 and 100 kg N per hectare (Table 3).

\section{Yield components}

The cutting date and the stage of development of timothy had statistically very significant effects on the proportion of leaves and stems in the primary growth $(p<0.001)$. At the pasture stage, more than half of the dry matter yield consisted of leaves but at the late silage stage the proportion of leaves was only $25 \%$ (Table 3 ). The most rapid change in the leaf to stem ratio was at the beginning of heading. There was a very strong positive correlation between the proportion of stems and the amount of dry matter in the primary yield ( $r=0.84, p<0.001)$. Nitrogen fertilization did not have a statistically significant effect on the proportions of the yield components $(p=0.17)$.

When the first cut was done normally at the silage stage, the average proportion of stems at the end of August after a growing period of the two 
Vol. 19(2010): 252-268.

Table 3. Accumulation of dry matter and composition of yields in 1999-2001.

\begin{tabular}{|c|c|c|c|c|c|c|c|}
\hline \multirow{2}{*}{\multicolumn{2}{|c|}{$\begin{array}{l}\text { Treatment/ } \\
\text { cutting date }\end{array}$}} & \multicolumn{2}{|c|}{$\begin{array}{l}\text { Dry matter } \\
\mathrm{kg} \mathrm{ha}^{-1}\end{array}$} & \multicolumn{2}{|c|}{$\begin{array}{c}\text { Yield components } \\
\text { Leaf to stem ratio, \% }\end{array}$} & \multicolumn{2}{|c|}{$\begin{array}{l}\text { Increase of dry matter } \\
\text { in a day, } \mathrm{kg} \mathrm{ha}^{-1}\end{array}$} \\
\hline & & $80 \mathrm{~N}^{1}$ & $100 \mathrm{~N}$ & $80 \mathrm{~N}$ & $100 \mathrm{~N}$ & $80 \mathrm{~N}$ & $100 \mathrm{~N}$ \\
\hline \multicolumn{8}{|c|}{ Primary growth: } \\
\hline $\mathrm{EP}^{2}$ & 14.6. & 1211 & 1336 & $56: 44$ & $53: 47$ & & \\
\hline $\mathrm{LP}^{3}$ & 18.6. & 1855 & 2047 & $42: 58$ & $42: 58$ & 161 & 178 \\
\hline $\mathrm{ES}^{4}$ & 23.6 . & 3054 & 3169 & $32: 68$ & $32: 68$ & 240 & 224 \\
\hline $\mathrm{S}^{5}$ & 28.6 . & 4115 & 4034 & $28: 72$ & $29: 71$ & 212 & 173 \\
\hline \multirow[t]{2}{*}{$\mathrm{LS}^{6}$} & 3.7. & 5211 & 5033 & $25: 75$ & $26: 74$ & 219 & 200 \\
\hline & & $\mathrm{SE}^{10}=103$ & & $\mathrm{SE}=\mathrm{NA}$ & & 211 & $\begin{array}{c}195 \\
\text { (mean EP-LS) }\end{array}$ \\
\hline \multicolumn{8}{|c|}{ Regrowth: } \\
\hline $4 W^{7}$ & 26.7. & 1429 & 1399 & $73: 27$ & $74: 26$ & & \\
\hline $6 \mathrm{~W}^{8}$ & 9.8 . & 2598 & 2942 & $61: 39$ & $61: 39$ & 84 & 110 \\
\hline \multirow[t]{2}{*}{$8 \mathrm{~W}^{9}$} & 24.8. & 3544 & 3852 & $48: 52$ & $48: 52$ & 63 & 61 \\
\hline & & $\mathrm{SE}=152$ & & $\mathrm{SE}=\mathrm{N} A$ & & 73 & $\begin{array}{c}85 \\
\text { (mean } 4 \mathrm{~W}-8 \mathrm{~W} \text { ) }\end{array}$ \\
\hline
\end{tabular}

${ }^{1} \mathrm{~N}$-nitrogen fertilization, ${ }^{2} \mathrm{EP}$-early pasture, ${ }^{3} \mathrm{LP}$-late pasture, ${ }^{4} \mathrm{ES}$-early silage, ${ }^{5} \mathrm{~S}$-silage, ${ }^{6} \mathrm{LS}$-late silage, ${ }^{7} 4 \mathrm{~W}-4$ weeks after the first cut, ${ }^{8} 6 \mathrm{~W}-6$ weeks after the first cut, ${ }^{9} 8 \mathrm{~W}-8$ weeks after the first cut, ${ }^{10} \mathrm{SE}$-standard error of mean, ${ }^{11} \mathrm{SE}=\mathrm{NA}$-standard error is not available due to arcsinetransformation

months was not more than 52\% (Table 3 ). Only the very early first harvest at the pasture stage resulted in more notable stem formation in the regrowth. In the yields of young first-year timothy stands, the proportion of leaves both in the first harvest and in the regrowth was greater than in the older leys. $\mathrm{Ni}$ trogen fertilization had no statistically significant effect on the proportion of the yield components $(p=0.95)$.

\section{Crude protein content}

Following a nitrogen fertilization treatment of 80 $\mathrm{kg} \mathrm{ha}^{-1}$, the average crude protein content in dry matter at the early pasture stage was $20.9 \%$, but 19 days later, at the late silage stage, it was only $8.8 \%(S E=0.23 \%, p<0.001)$. A treatment of $100 \mathrm{~kg} \mathrm{~N} \mathrm{ha}^{-1}$ resulted in a higher protein content, the respective values being $22.5 \%$ and $10.0 \%$ ( $S E$ $=0.23 \%, p<0.001$ ) respectively (Table 4 ). From the silage stage onwards, the crude protein content in primary growth was not related to the amount of dry matter. The level of nitrogen fertilization had a statistically significant effect on the crude protein content in dry matter $(p=0.01)$. The fastest daily decrease, 1.0 percentage unit $(S E=0.03 \%)$, in the crude protein content was at the pasture stage and it was the same for both nitrogen levels. This maturity stage also coincided with the greatest variation in the crude protein content between the trial years. From this growth stage onwards, the daily decline in crude protein content declined and was about 0.40 percentage units $(S E=0.03 \%)$ at the late silage stage. The average daily decrease in crude protein content in timothy swards over the entire sampling period was 0.65 percentage units $(S E=0.01 \%)$.

The main cause for the rapid decrease in the crude protein content of timothy yields is in the high proportion of stems and the low protein content of the stem component. At the stage of full heading, the leaf to stem ratio in timothy stands was 26:74. Even when $100 \mathrm{~kg} \mathrm{ha}^{-1}$ nitrogen was applied, the 
Nissinen, O. et al. Dry matter yield and nutritive value of timothy

Table 4. Average development of crude protein (CP, \% in dry matter) content in yield, leaves and stems in 1999-2001.

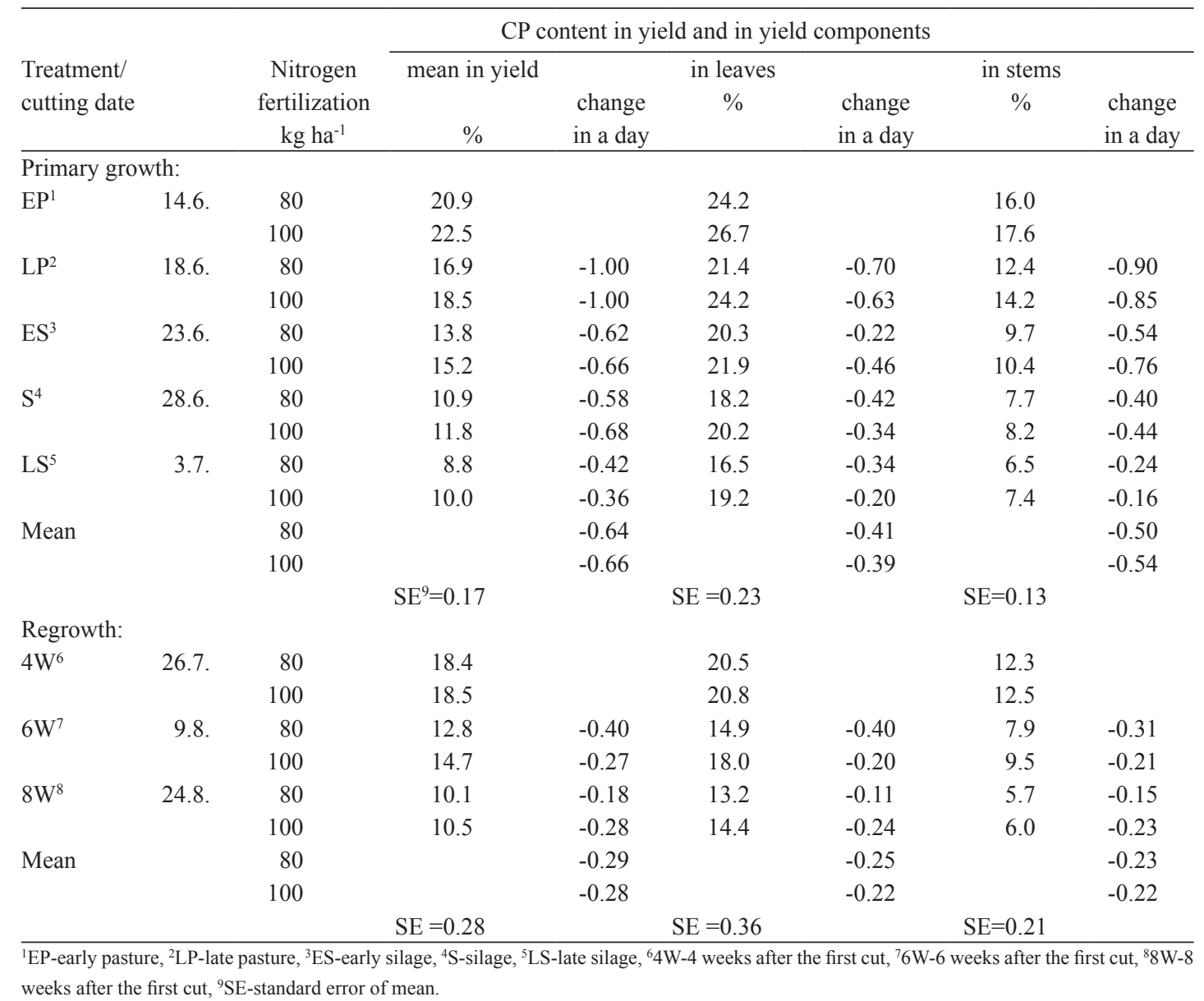

crude protein content of the straw component was $17.6 \%$ at the earlier pasture stage and only $7.4 \%$ at the late silage stage (Table 4). The crude protein content of the leaves was $26.7 \%$ and $19.2 \%$ ( $S E=$ $0.23 \%$ ), respectively. The average daily decline in the protein content was 0.54 percentage units in the stem component $(S E=0.01 \%)$ and 0.39 percentage units in the leaf component $(S E=0.02 \%)$.

The average daily decline in the crude protein content in the regrowth was 0.28 percentage units $(S E=0.01 \%, p<0.001)$, and it decreased during the last four weeks before the second harvest from 18.5 to $10.5 \%(S E=0.28 \%)$. The protein content in the leaves decreased during the sampling period from $20.8 \%$ to $14.4 \%(S E=0.50 \%, p<0.001)$ and in the stem material from $12.5 \%$ to $6.0 \%$ ( $S E$ $=0.32 \%, p<0.001$ ) (Table 4). In the regrowth, too, the crude protein content was somewhat higher following the $100 \mathrm{~kg} \mathrm{~N} \mathrm{ha}^{-1}$ treatment than when applying $80 \mathrm{~kg} \mathrm{~N} \mathrm{ha}^{-1}$ ( $p=0.03$ ), but the daily decrease was nearly the same for both nitrogen levels $(p=0.07)$. The crude protein content both in the in the leaves and in the stems was lower in the regrowth than that in the primary growth throughout the sampling periods. 
Vol. 19(2010): 252-268.

The age of the ley had a statistically significant effect on the content of crude protein $(p<0.001)$. The protein content both in the yield, the leaves and the stem had a statistically significant positive correlation with the age of the ley and this was found to be especially so in the aftermath $(p<0.001$ for all relationships).

\section{Organic matter digestibility}

The stage of development of timothy had a statistically very significant effect on forage digestibility ( $p$ $<0.001)$. Neither the amount of dry matter nor the accumulation of effective day-degrees had a distinct impact on digestibility. As regards dry matter yield, the decline in organic matter digestibility was from $80 \%$ at the early pasture stage to $63 \%$ at the late silage stage. The average daily decrease was 0.9 percentage units (Table 5) and this decrease was similar at both levels of nitrogen fertilization $(p=$ 0.64 ). The most noteworthy change was noticed after the first visible heads appeared, especially at the silage stage (when $30-60 \%$ of stems are heading) at which point in time digestibility decreased by more than one percentage unit per day. The rapid decline of organic matter digestibility was due to the low digestibility of the stem component. At the silage stage, the average daily decline in digestibility of the leaves was 0.66 percentage units, but that of the stem component was as high as 1.82 percentage units. Also, the variation in the digestibility of the dry matter was at its maximum at this stage of development between the trial years. The average digestibility of leaves decreased from $81 \%$ to $73 \%$ and that of stems from $79 \%$ to $58 \%$ between the early pasture stage and the late silage stage. The higher rate of nitrogen fertilization (100 $\mathrm{kg} \mathrm{N} \mathrm{ha}{ }^{-1}$ ) resulted in slightly lower forage digestibility $(p=0.06)$.

In the regrowth, the average daily decline in forage digestibility was very slow, $0.11 \%$, decreasing from $78 \%$ to $75 \%$ (Table 5), but statistically it was significant $(p<0.001)$. Moreover, there was no practically important difference in digestibility between the leaves and the stems. During the 4-week period before the second cut, the change in the digestibility of the leaves meant a drop from $79 \%$ to $77 \%$ and that of the stem component from $78 \%$ to $73 \%$. The daily decline was 0.08 and 0.17 percentage units, respectively. In the regrowth, too, the higher nitrogen fertilization treatment of 100 $\mathrm{kg} \mathrm{N} \mathrm{ha}{ }^{-1}$ resulted in a slightly lower digestibility of swards than that caused by a treatment of 80 $\mathrm{kg} \mathrm{ha}^{-1}$, but the difference was not statistically significant $(p=0.11)$. It was also noteworthy that the date of the first cut had a relatively small impact on the forage digestibility of the regrowth in the late summer. Even when the first harvest was done at the early pasture stage in mid June, the forage digestibility of the aftermath harvested at the end of August was still about $67 \%$ in dry matter despite the rather high proportion of stems, $66 \%$, in the yield.

On average, there was positive, statistically significant correlation between digestibility and age of the ley in spring growth. In the regrowth, however, the organic matter digestibility decreased with the ageing of the ley. The wide extent of winter damage increased significantly the organic matter digestibility.

\section{Discussion}

\section{Dry matter yields}

After the late start in growth, swards of timothy exhibit a fast growth rate and a rapid change in the nutritive value of the primary growth (Thorvaldsson and Andersson 1986). Besides winter damage, the 24-hour photoperiod reduces tiller density and the number of lateral shoots (Heide 1982). Daily increases of $110-150 \mathrm{~kg} \mathrm{ha}^{-1}$ in dry matter in primary growth and 50-70 $\mathrm{kg} \mathrm{ha}^{-1}$ in regrowth have been recorded in timothy swards (Huokuna and Hakkola 1984, Thorvaldsson and Andersson 1986, Hakkola and Nykänen-Kurki 1994, Rinne and Nykänen 2000).

In the present study, the most rapid increase in dry matter, 220-240 $\mathrm{kg} \mathrm{ha}^{-1}$ in a day, was meas- 
Nissinen, O. et al. Dry matter yield and nutritive value of timothy

Table 5. Average development of organic matter digestibility (OMD) in yield, leaves and stems in 1999-2001. Arcsine -trasformation were made before statistical analysis and standard error of means was not possible to transform back to the original scale.

\begin{tabular}{|c|c|c|c|c|c|c|c|c|}
\hline \multirow[b]{2}{*}{$\begin{array}{l}\text { Treatment/ } \\
\text { cutting date }\end{array}$} & & \multirow[b]{2}{*}{$\begin{array}{c}\text { Nitrogen } \\
\text { fertilization } \\
\mathrm{kg} \mathrm{ha}^{-1}\end{array}$} & \multicolumn{6}{|c|}{ Decrease of OMD in yield and in yield components } \\
\hline & & & $\begin{array}{c}\text { mean in yield } \\
\%\end{array}$ & $\begin{array}{l}\text { change } \\
\text { in a day }\end{array}$ & $\begin{array}{c}\text { in leaves } \\
\%\end{array}$ & $\begin{array}{l}\text { change } \\
\text { in a day }\end{array}$ & $\begin{array}{c}\text { in stems } \\
\%\end{array}$ & $\begin{array}{l}\text { change } \\
\text { in a day }\end{array}$ \\
\hline \multicolumn{9}{|c|}{ Primary growth: } \\
\hline \multirow[t]{2}{*}{$\mathrm{EP}^{1}$} & 14.6. & 80 & 80.8 & & 81.1 & & 79.6 & \\
\hline & & 100 & 79.8 & & 80.9 & & 79.0 & \\
\hline \multirow[t]{2}{*}{$\mathrm{LP}^{2}$} & 18.6. & 80 & 79.3 & -0.38 & 79.3 & -0.45 & 77.4 & -0.55 \\
\hline & & 100 & 78.6 & -0.30 & 78.5 & -0.60 & 75.8 & -0.80 \\
\hline \multirow[t]{2}{*}{$\mathrm{ES}^{3}$} & 23.6. & 80 & 74.8 & -0.90 & 77.2 & -0.42 & 72.3 & -1.02 \\
\hline & & 100 & 74.1 & -0.90 & 77.2 & -0.26 & 71.8 & -0.80 \\
\hline \multirow[t]{2}{*}{$\mathrm{S}^{4}$} & 28.6 . & 80 & 69.6 & -1.04 & 74.0 & -0.64 & 63.5 & -1.76 \\
\hline & & 100 & 68.2 & -1.18 & 73.8 & -0.68 & 62.4 & -1.88 \\
\hline \multirow[t]{2}{*}{$\mathrm{LS}^{5}$} & 3.7. & 80 & 63.6 & -1.20 & 73.0 & -0.20 & 58.7 & -0.96 \\
\hline & & 100 & 63.8 & -0.88 & 73.3 & -0.10 & 58.9 & -0.70 \\
\hline \multirow[t]{2}{*}{ Mean } & & 80 & & -0.91 & & -0.43 & & -1.10 \\
\hline & & 100 & & -0.84 & & -0.40 & & -1.06 \\
\hline \multicolumn{9}{|l|}{ Regrowth: } \\
\hline \multirow[t]{2}{*}{$4 W^{6}$} & 26.7 . & 80 & 78.5 & & 79.2 & & 78.8 & \\
\hline & & 100 & 77.8 & & 79.1 & & 77.9 & \\
\hline \multirow[t]{2}{*}{$6 \mathrm{~W}^{7}$} & 9.8. & 80 & 77.3 & -0.09 & 77.5 & -0.12 & 76.0 & -0.20 \\
\hline & & 100 & 76.0 & -0.13 & 77.4 & -0.12 & 75.2 & -0.19 \\
\hline \multirow[t]{2}{*}{$8 W^{8}$} & 24.8 . & 80 & 74.8 & -0.17 & 77.0 & -0.03 & 73.8 & -0.15 \\
\hline & & 100 & 75.3 & -0.05 & 76.7 & -0.05 & 72.9 & -0.15 \\
\hline \multirow[t]{2}{*}{ Mean } & & 80 & & -0.13 & & -0.08 & & -0.17 \\
\hline & & 100 & & -0.09 & & -0.08 & & -0.17 \\
\hline
\end{tabular}

${ }^{1}$ EP-early pasture, ${ }^{2}$ LP-late pasture, ${ }^{3}$ ES-early silage, ${ }^{4}$ S-silage, ${ }^{5}$ LS-late silage, ${ }^{6} 4 \mathrm{~W}-4$ weeks after the first cut, ${ }^{7} 6 \mathrm{~W}-6$ weeks after the first cut, ${ }^{8} 8 \mathrm{~W}-8$ weeks after the first cut

ured around the beginning of the heading stage and about $40 \%$ of the entire primary yield was formed during the following ten days. Only 336 effective growing day-degrees were accumulated in primary growth from the beginning of the growing season until full heading. This meant the production of 15 $\mathrm{kg}$ of dry matter per each $1{ }^{\circ} \mathrm{C}$ increment of cumulative effective day-degrees. After the first cut 528 ${ }^{\circ} \mathrm{C}$ effective growing day-degrees were needed to produce the second silage yield of $3700 \mathrm{~kg}$ DM $\mathrm{ha}^{-1}$. The accumulation of dry matter was only 7 $\mathrm{kg}$ per each $1{ }^{\circ} \mathrm{C}$ increment of the effective daydegrees. The inherent growth rhythm of northern timothy varieties results in weak regrowth, which is not very much influenced by the relatively favourable weather conditions in August. Despite the slow growth rate in the late summer in Northern Finland, the regrowth comprises nearly half of the total herbage yield. In the present study, the highest increase in the dry matter in the regrowth occurred during two weeks in late July and early August. More than $60 \%$ of the total dry matter of the regrowth accumulated during the last four weeks of the growing period of two months. The harvesting of the regrowth in late August is early enough for acclimation. Moreover, the harvesting method used 
Vol. 19(2010): 252-268.

Table 6. Relationship between accumulation of effective growing day-degrees (GDD) and decline in organic matter digestibility (OMD) and in crude protein (CP) content, mean in 1999-2001.

\begin{tabular}{|c|c|c|c|c|c|c|c|c|c|c|}
\hline \multirow{3}{*}{$\begin{array}{l}\text { Stage of } \\
\text { development } \\
\text { (days) }\end{array}$} & & \multirow{3}{*}{$\begin{array}{l}\text { Accumulation } \\
\text { of GDD, }{ }^{\circ} \mathrm{C}\end{array}$} & \multicolumn{8}{|c|}{ Decrease in $\mathrm{OMD}$ and in $\mathrm{CP}$} \\
\hline & & & \multicolumn{4}{|c|}{$\%$ units } & \multicolumn{4}{|c|}{$\begin{array}{l}\% \text { units per each } 1{ }^{\circ} \mathrm{C} \\
\text { increment of GDD }\end{array}$} \\
\hline & & & $80 \mathrm{~N}^{1}$ & $100 \mathrm{~N}$ & $80 \mathrm{~N}$ & $100 \mathrm{~N}$ & $80 \mathrm{~N}$ & $100 \mathrm{~N}$ & $80 \mathrm{~N}$ & $100 \mathrm{~N}$ \\
\hline $\mathrm{EP}-\mathrm{LP}$ & (4) & 35 & -1.5 & -1.2 & -4.0 & -4.0 & 0.04 & 0.03 & 0.11 & 0.11 \\
\hline $\mathrm{LP}-\mathrm{ES}$ & $(5)$ & 38 & -4.5 & -4.5 & -3.1 & -3.3 & 0.12 & 0.12 & 0.08 & 0.09 \\
\hline $\mathrm{ES}-\mathrm{S}$ & (5) & 55 & -5.2 & -5.9 & -2.9 & -3.4 & 0.09 & 0.11 & 0.05 & 0.06 \\
\hline$S-L S$ & $(5)$ & 60 & -6.0 & -4.4 & -2.1 & -1.8 & 0.10 & 0.07 & 0.04 & 0.03 \\
\hline
\end{tabular}

${ }^{1} \mathrm{~N}$-nitrogen fertilization, $\mathrm{kg} \mathrm{ha}^{-1}$

Stages of growth: EP - early pasture, LP - late pasture, ES - early silage, S - silage, LS - late silage

during the growing season does not seem to have any distinct impact on the overwintering of timothy (Nissinen and Hakkola 1995).

\section{Nutritive value}

Changes in the nutritive value of plants forming the primary growth are caused not only by the rapidly increasing proportion of stems, but also by the changes occurring within the stems and the leaves (Terry and Tilley 1964, Salo et al. 1975, Thorvaldsson 1988). Trials conducted in Finland and Sweden have demonstrated that the decline in the crude protein has been around 0.30 percentage units per day in the primary growth and about 0.20 percentage units per day in the regrowth (Huokuna and Hakkola 1984, Thorvaldsson and Andersson 1986). According to Thorvaldsson (1987) and Thorvaldsson and Fagerberg (1988), the crude protein content is closely associated with phenological development and the rate of dry matter accumulation.

In the present study, the fastest daily decrease in crude protein content, 1.0 percentage unit, occurred at the pasture (leaf) stage. This rate was very fast when compared, for example, to the decrease of 0.40 percentage units reported by Fagerberg (1988) at the same stage of development in Southern Sweden. In the regrowth, the average daily decline in the crude protein content was 0.28 percentage units. The crude protein content both in the leaves and in stems was lower in the regrowth than that in the primary growth throughout the sampling period. Although the crude protein content decreases less rapidly in the regrowth than in the primary growth, the mean protein content of the dry matter of the second silage yield in the present study was only about $10 \%$. In late summer, the crude protein content was relatively low both in the stem component and in the leaves.

Daily declines in digestibility of about 0.50 percentage units have been reported for primary growth and less than 0.20 percentage units for regrowth (Thorvaldsson and Andersson 1986, Rinne 2000, Sihto and Rinne 2008). In the study by Gustavsson and Martinsson (2004), both the concentration and digestibility of the cell walls were markedly related to the growth of dry matter and more so than to plant development or the proportion of leaf matter. At harvest time, the growth of stems and the change in stem properties are important factors, because the leaf growth rates were very slow at that time. In the present study, digestibility of the primary growth was closely connected with the maturity stage of timothy. The biggest variation in dry matter yield and digestibility between the trial years was found to occur around the onset of heading. However, despite the variable amounts of 
Nissinen, O. et al. Dry matter yield and nutritive value of timothy

Table 7. Statistical significances ( $\mathrm{p}$-values) for all main and interaction effects.

\begin{tabular}{|c|c|c|c|}
\hline Variable & $\begin{array}{l}\text { Source of } \\
\text { variation }\end{array}$ & $\begin{array}{l}\text { Statistical significance } \\
\text { (primary growth) }\end{array}$ & $\begin{array}{c}\text { Statistical significance } \\
\text { (regrowth) }\end{array}$ \\
\hline \multirow[t]{8}{*}{ Dry matter yield (DMY) } & & & \\
\hline & Nitrogen $(\mathrm{N})$ & 0.91 & 0.15 \\
\hline & Treatment (T) & $<0.001$ & $<0.001$ \\
\hline & $\mathrm{N} \times \mathrm{T}$ & 0.68 & 0.66 \\
\hline & Year $(Y)$ & $<0.001$ & 0.04 \\
\hline & Y x N & $<0.01$ & 0.27 \\
\hline & Y x T & $<0.001$ & 0.15 \\
\hline & $\mathrm{Y} \times \mathrm{N} \times \mathrm{T}$ & 0.18 & 0.22 \\
\hline \multirow{7}{*}{ Leaf to stem ratio } & Nitrogen $(\mathrm{N})$ & 0.17 & 0.95 \\
\hline & Treatment $(\mathrm{T})$ & $<0.001$ & $<0.001$ \\
\hline & $\mathrm{N} x \mathrm{~T}$ & 0.08 & 0.82 \\
\hline & Year $(Y)$ & $<0.01$ & 0.01 \\
\hline & $\mathrm{Y} \times \mathrm{N}$ & 0.08 & 0.64 \\
\hline & $\mathrm{Y} \times \mathrm{T}$ & $<0.01$ & $<0.001$ \\
\hline & $\mathrm{Y} \times \mathrm{N} \times \mathrm{T}$ & 0.01 & 0.38 \\
\hline \multirow{7}{*}{ Crude protein content (CP) in yield } & Nitrogen $(\mathrm{N})$ & 0.01 & 0.03 \\
\hline & Treatment (T) & $<0.001$ & $<0.001$ \\
\hline & $\mathrm{N} x \mathrm{~T}$ & 0.48 & 0.07 \\
\hline & Year $(Y)$ & $<0.01$ & $<0.001$ \\
\hline & $\mathrm{Y} \times \mathrm{N}$ & 0.23 & 0.97 \\
\hline & $\mathrm{Y} \times \mathrm{T}$ & $<0.001$ & $<0.001$ \\
\hline & $\mathrm{Y} \times \mathrm{N} \times \mathrm{T}$ & 0.08 & $<0.01$ \\
\hline \multirow{7}{*}{ Crude protein content $(\mathrm{CP})$ in leaves } & Nitrogen $(\mathrm{N})$ & 0.01 & 0.03 \\
\hline & Treatment $(\mathrm{T})$ & $<0.001$ & $<0.001$ \\
\hline & $\mathrm{N} x \mathrm{~T}$ & 0.15 & 0.18 \\
\hline & Year $(Y)$ & $<0.001$ & $<0.001$ \\
\hline & $\mathrm{Y} \times \mathrm{N}$ & 0.66 & 0.68 \\
\hline & $\mathrm{Y} \times \mathrm{T}$ & $<0.001$ & $<0.001$ \\
\hline & $\mathrm{Y} \times \mathrm{N} \times \mathrm{T}$ & 0.24 & 0.32 \\
\hline \multirow{7}{*}{ Crude protein content $(\mathrm{CP})$ in stems } & Nitrogen $(\mathrm{N})$ & 0.02 & 0.06 \\
\hline & Treatment $(\mathrm{T})$ & $<0.001$ & $<0.001$ \\
\hline & $\mathrm{N} \times \mathrm{T}$ & $<0.001$ & 0.11 \\
\hline & Year $(Y)$ & $<0.01$ & 0.01 \\
\hline & $\mathrm{Y} \times \mathrm{N}$ & 0.07 & 0.43 \\
\hline & Y x T & $<0.001$ & $<0.001$ \\
\hline & $\mathrm{Y} \times \mathrm{N} \times \mathrm{T}$ & 0.14 & 0.15 \\
\hline \multirow{7}{*}{ Organic matter digestibility (OMD) in yield } & Nitrogen $(\mathrm{N})$ & 0.05 & 0.22 \\
\hline & Treatment $(\mathrm{T})$ & $<0.001$ & $<0.001$ \\
\hline & $\mathrm{N} \times \mathrm{T}$ & 0.64 & 0.60 \\
\hline & Year $(Y)$ & $<0.01$ & $<0.001$ \\
\hline & $\mathrm{Y} \times \mathrm{N}$ & 0.15 & 0.19 \\
\hline & $\mathrm{Y} \times \mathrm{T}$ & $<0.001$ & $<0.01$ \\
\hline & $\mathrm{Y} \times \mathrm{N} \times \mathrm{T}$ & $<0.01$ & 0.99 \\
\hline \multirow[t]{7}{*}{ Organic matter digestibility (OMD) in leaves } & Nitrogen $(\mathrm{N})$ & 0.27 & 0.41 \\
\hline & Treatment $(\mathrm{T})$ & $<0.001$ & $<0.001$ \\
\hline & $\mathrm{N} \times \mathrm{T}$ & 0.11 & 0.43 \\
\hline & Year $(Y)$ & 0.03 & $<0.001$ \\
\hline & $\mathrm{Y} \times \mathrm{N}$ & 0.10 & 0.26 \\
\hline & $\mathrm{Y} \times \mathrm{T}$ & $<0.001$ & $<0.01$ \\
\hline & $\mathrm{Y} \times \mathrm{N} \times \mathrm{T}$ & 0.18 & $<0.01$ \\
\hline \multirow[t]{7}{*}{ Organic matter digestibility (OMD) in stems } & Nitrogen (N) & 0.06 & 0.11 \\
\hline & Treatment $(\mathrm{T})$ & $<0.001$ & $<0.001$ \\
\hline & $\mathrm{N} \times \mathrm{T}$ & $<0.01$ & 0.87 \\
\hline & Year (Y) & $<0.001$ & $<0.001$ \\
\hline & $\mathrm{Y} \times \mathrm{N}$ & 0.24 & 0.24 \\
\hline & $\mathrm{Y} \times \mathrm{T}$ & $<0.001$ & $<0.01$ \\
\hline & $\mathrm{Y} \times \mathrm{N} \times \mathrm{T}$ & 0.02 & 0.76 \\
\hline
\end{tabular}


Vol. 19(2010): 252-268.

dry matter, the differences in nutritive value levelled out at the time of full heading (Fig.1).

When compared with many other reports, this study showed a more rapid average decline in organic matter digestibility in the primary growth, 0.87 percentage units in a day, but a slower decline in the regrowth, 0.11 percentage units. The most noteworthy difference was noted after the first visible heads appeared, especially at the silage stage (30-60\% of the stems heading) when digestibility declined by more than one percentage unit in a day. The rapid decline in organic matter digestibility was due to the low digestibility of the stem component.

The rapid decrease in the crude protein content in the present study was found in the first two samplings at the 4-5 leaf stage in mid June, about 3-4 weeks after the actual onset of growth. On the other hand, the distinct decline in organic matter digestibility was to be seen at the time of ear emergence and about one week later than the very rapid decrease in the crude protein content. Since the crude protein content in the primary growth begins to decline already at an early growth stage when the yield is low, it is more important to fit acceptable digestibility with a reasonably high dry matter yield. The amount of dry matter in relation to the nutritive value seems to be at its best when half of the heads of timothy are visible. At this stage of development of the timothy stands, the changes in yield and quality are very rapid, and the optimal nutritive value of timothy can be missed out on even if the delay in harvesting is just 2-3 days. Harvesting should be started when one fifth of the heads of timothy are visible, and it should be completed within one week. This is the appropriate time for the first cut also with respect to maximizing the short growing period. Also, the differences in dry matter yields and in the herbage nutritive value between the years and swards of different ages are levelled out by the time of full heading and early flowering (Nissinen 2001, Belanger et al. 2008). Despite the low protein content in the regrowth, fairly high and good digestible dry matter yields are produced and the timing of the last harvest can be based mainly on good wintering.

\section{Temperature and photoperiod}

The primary growth's more rapid phenological development at higher temperatures has been observed in many experiments. Also, the leaf proportion has been noted to decline more rapidly at higher temperatures (Fagerberg 1988, Thorvaldsson 1988, Nordang and Lunnan 1994). A rise in temperature has the effect of increasing the rate of decline in digestibility in the first crop (Thorvaldsson 1987, 2006, Rinne et al. 2001, Sihto and Rinne 2008). The optimum daytime temperature for the growth of timothy in summer appears to be around $17^{\circ} \mathrm{C}$ (Bertrand et al. 2008, Nordheim-Viken et al. 2009). Under cooler temperatures, dry matter digestibility has been higher as a result of increase in cell wall digestibility and partly of delay in reaching a certain stage of development.

The present study revealed that the rapid increase of effective day-degrees at the pasture stage had a significant effect on the date of the first visible heads appearing and at that point in time also on the amount of dry matter and organic matter digestibility, but changes in yield and forage quality occurring during the actual heading stage were not influenced by the weather conditions. The experiment by Nordang and Lunnan (1994) indicates that at the time of heading temperature has only a minor impact on the digestibility of timothy. This is explained by the combined effects of temperature on the digestibility of plant fractions, the proportion of leaf blades, and phenological development. Also, according to Ames et al. (1993), although more lignin tended to be produced at higher growing temperatures, there is no single temperature that simulates the field growing conditions which range throughout the season.

The different development of regrowth digestibility compared to that of primary growth may be caused by the lower growth temperatures retarding lignin synthesis (Van Soest et al. 1978) and differences in the growth pattern, since the proportion of leaves in the total herbage mass did not decline with the advance in grass growth during the autumn (Åman and Lindgren 1983, Rinne et al. 2000). However, the daily mean temperature in Rovanie$\mathrm{mi}$ in June is $12^{\circ} \mathrm{C}$ and in August it is $13^{\circ} \mathrm{C}$. Also 


\section{AGRICULTURAL AND FOOD SCIENCE}

\section{Nissinen, O. et al. Dry matter yield and nutritive value of timothy}

the precipitation in July and August is higher than in May and June. Thus, weather conditions do not explain the low crude protein content and high organic matter digestibility in the regrowth compared with the corresponding primary growth values.

The long photoperiod in northern conditions stimulates the dry matter production of timothy and this stimulation compensates for the several degrees of reduction in temperature (Heide 1982). In the study by Andersen and Østgård (1980) the crude protein content increased with decreasing photoperiod while that of crude fibre decreased. Similarly in the study by Nordheim-Viken et al. (2009) in a controlled environment, the crude protein content was lower in the 24-hour samples than in the 18-hour samples, mainly because of the lower crude protein content at beginning of heading. However, the photoperiod has little impact on digestibility (Thorvaldsson 1987, Nordheim-Viken et al. 2009). While the photoperiod during the first half of August is still 17-19 hours in Rovaniemi (Moisio 2007), the day length is not a limiting factor for dry matter production in the regrowth. Also, the lower crude protein content in the regrowth compared with that in the primary growth is not explained by the shorter photoperiod.

\section{Nitrogen fertilization}

The uptake of nitrogen in the northern growing conditions is inadequate due to the very rapid growth of timothy at the time of the heading stage, and this also results in low crude protein content in the primary yield (Deinum et al. 1981, Thorvaldsson 1987). Generally, crude protein content has increased with increased nitrogen application (Huokuna and Hakkola 1984, Thorvaldsson and Andersson 1986). In Northern Finland, the optimum $\mathrm{N}$ fertilization rate for herbage yield formation in two-cut system is around $100 \mathrm{~kg}$ ha-1 per yield (MTT Rovaniemi, trial results in 1985-1990, unpublished). There is also a good response of yield to $\mathrm{N}$ fertilization and $\mathrm{N}$ leaching risk is minimized. That is also supported by many other investigations (Thorvaldsson and Andersson 1986, Lunnan and Nesheim 2002,
Belanger et al. 2008). Although the lost of nitrogen increased with increasing level of nitrogen application, according to Lunnan and Nesheim (2002), spring application rate should not be too low in order to ensure both high yield in the first cut and sufficient plant $\mathrm{N}$ reserves in stubble and roots to ensure a rapid regrowth.

In the present study, the higher amount of nitrogen increased the early growth of timothy but the differences in dry matter leveled off by the time of silage stage. Nitrogen fertilization had no significant effect either on the proportion of different yield components.

The effect of nitrogen fertilization on digestibility has been variable. In Northern Sweden, increased nitrogen has given a faster decline in digestibility and the effect has been greater in second crop (Thorvaldsson and Andersson 1986). Also in the present study the higher nitrogen fertilization gave a lower forage digestibility both in primary growth and in regrowth.

\section{Conclusions}

In timothy, the short period from the first visible heads to full heading is a critical time in respect to amount and quality of the whole primary yield in Northern Finland. The most rapid daily increase of dry matter is measured around the beginning of heading stage and during the following ten days about $40 \%$ of the entire primary yield is formed. The fastest decrease in crude protein content occurs at the pasture stage (4-5 leaf-stage) being one percentage unit per day. The decline in organic matter digestibility in the early primary growth is slow, but after the first visible heads have appeared digestibility decreases by more than one percentage unit per day. Because crude protein begins to decline already in the early growth stage accompanied by low yield, it is more important in the short northern growing period to balance good digestibility with a reasonably high dry matter yield. Also, the differences in dry matter yields and in the nutritive value of the herbage between productive years and swards of different 
Vol. 19(2010): 252-268.

ages level out at the stage of full heading. With the qualitative properties changing relatively slowly in late summer, the harvest date of the regrowth can be selected considering mainly the requirements for good overwintering of timothy.

Acknowledgements. Dr. Oiva Niemeläinen is warmly acknowledged for his valuable comments on the manuscript.

\section{References}

Åman, P. \& Lindgren, E. 1983. Chemical composition and in vitro degradability of individual chemical constituents of six Swedish grasses harvested at different stages of maturity. Swedish Journal of Agricultural Research 13: 221-227.

Ames, N., McElroy, A.R. \& Erfle, J. 1993. The effect of temperature on quality characteristics in timothy (Phleum pratense L.) genotypes. Canadian Journal of Plant Science 73: 1017-1026.

Andersen, I.L. \& Østgård, O. 1980. Virkning av daglengde og nattbelysning på vekst, stoffinnhold, morfologi og overvintring hos noen grasarter. (The effect of daylength and night illumination on the growth, composition, morphology and overwintering of some grass species.) Statens forskingsstasjon Holt, Tromsø, Melding nr. 60. p. 417-432. (in Norwegian with English summary)

AOAC, 1990. Official Methods of Analysis. Association of Official Analytical Chemists, Inc., Arlington, VA. $1298 \mathrm{p}$.

Belanger, G., Tremblay, G.F. \& Mongrain, D. 2008. Yield and nutritive value of the spring growth of an ageing timothy sward. Canadian Journal of Plant Science 88: 457-464.

Bertrand, A., Tremblay, G.F., Pelletier, S. Castonguay, Y. \& Belanger, G. 2008. Yield and nutritive value of timothy as affected by temperature, photoperiod and time of harvest. Grass and Forage Science 63: 421-432.

Deinum, B., Beyer, J. de, Nordfelt, P.H., Kornher, A., Ostgård, O. \& Bogaert, G. van 1981. Quality of herbage at different latitudes. Netherlands Journal of Agricultural Science 29: 141-150.

Fagerberg, B. 1988. The Change in Nutritive Value in Timothy, Red Clover and Lucerne in Relation to Phenological Stage, Cutting time and Weather Conditions. Acta Agriculturae Scandinavica. 38 (vol. 4): 347-362.

Friedel, K. 1990. Die Schätzung des energetischen Futterwertes von Grobfutter mit Hilfe einer Cellulasemethode. Wissenschaftliche Zeitschrift der Wilhelm-Pieck-Universität, Rostock. Matematische-naturwissenschaftliche Reihe. 39: 78-86. (in German with English summary).

Gustavsson, A.-M. \& Martinsson, K. 2004. Seasonal variation in biochemical composition of cell walls, digestibility, morphology, growth and phenology in timothy. Euro- pean Journal of Agronomy 20: 293-312.

Hakkola, H. \& Nykänen-Kurki, P. 1994. Effect of nitrogen fertilization and cutting time on the quality and variable cost of red clover and timothy herbage production. In: Grassland and Society. Proceedings of the $15^{\text {th }}$ General Meeting of the European Grassland Federation, Wageningen, The Netherlands, June 6-9 1994. p. 105-108.

Heide, O.M. 1982. Effects of Photoperiod and Temperature on Growth and Flowering in Norwegian and British Timothy Cultivars (Phleum pratense L.). Acta Agriculturae Scandinavica 32: 241-252.

Huokuna, E. \& Hakkola, H. 1984. Koiranheinän ja timotein kasvu ja rehuarvon muutokset säilörehuasteella (in Finnish). Maatalouden tutkimuskeskus. Tiedote 8/84. 54 p. (in Finnish)

Kuoppala, K., Rinne, M., Nousiainen, J. \& Huhtanen, P. 2008. The effect of cutting time of grass silage in primary growth and regrowth and the interactions between silage quality and concentrate level on milk production of dairy cows. Livestock Science 116: 171-182.

Lunnan, T. \& Nesheim, L. 2002. Response to Different Nitrogen Application Patterns on Grassland in a Two-cut System. Acta Agriculturae Scandinavica, Section B, Soil and Plant Science 52: 1-7.

Ministry of Agriculture and Forestry 2008. Yearbook of Farm Statistics 2007. Information Centre of the Ministry of Agriculture and Forestry (Tike), Helsinki. p. 105-107.

Moisio, O. 2007. Auringon nousu- ja laskuajat Suomessa (in Finnish). Cited 31 March 2009. Available on the internet: http://www.moisio.net/taivas/aurinko.php (in Finnish)

Nissinen, O. 1998. Timotei Lapin rehukasvina. (Timothy as a herbage grass in Lapland.) In: Salo, R. (ed.) Tutkimusta pohjoisella ulottuvuudella - MTT 100 vuotta. Maatalouden tutkimuskeskuksen julkaisuja. Sarja A. 40: 5056. (in Finnish with English abstract)

Nissinen, O. 2001. Effective growing degree days as a critical factor for yield and qualitative values of timothy in subarctic growing conditions. Proceedings of the XIX International Grassland Congress, Sao Pedro, Brazil 2001. p. 396-397.

Nissinen, O. \& Hakkola, H. 1994. Korjuutavan ja kasvilajin vaikutus nurmen tuottokykyyn Pohjois-Suomessa. (The effect of the harvesting method and plant species on the grassland productivity in north Finland.) Maatalouden tutkimuskeskus. Tiedote 19/94. 48 p. (in Finnish with English summary)

Nissinen, O. \& Hakkola, H. 1995. Effects of plant species and harvesting system on grassland production in northern Finland. Agricultural Science in Finland 4: 479-494.

Nordang, L. \& Lunnan, T. 1994. Effect of temperature on the digestibility of timothy. Workshop proceedings of the $15^{\text {th }}$ General Meeting of the European Grassland Federation, Wageningen, The Netherlands, 6-9 June 1994, p. 107-109.

Nordheim-Viken, H., Volden, H. \& Jørgensen, M. 2009. Effects of maturity stage, temperature and photoperiod on growth and nutritive value of timothy (Phleum pratense L.). Animal Feed Scienced and Technology 152: 204-218.

Pulli, S. 1989. Nurmiviljelyn ilmastolliset mahdollisuudet Suomessa. Leipä leveämmäksi. 1: 5-6. (in Finnish)

Rinne, M. 2000. Influence of the timing of the harvest of pri- 


\section{AGRICULTURAL AND FOOD SCIENCE}

\section{Nissinen, O. et al. Dry matter yield and nutritive value of timothy}

mary grass growth on herbage quality and subsequent digestion and performance in the ruminant animal. University of Helsinki, Department of Animal Science. Publications 54. 42 p. +5 encl.

Rinne, M., Hellämäki, M., Nousiainen, J., Aura, E. \& Huhtanen, P. 2000. Kevätkorjuun optimoinnista koko kesän nurmisadon hallintaan. Maataloustieteen päivät 2000, Kotieläintiede, Maaseutukeskusten liiton julkaisuja no 952. p. 126-129. (in Finnish)

Rinne, M. \& Nykänen, A. 2000. Timing of primary growth harvest affects the yield and nutritive value of timothyred clover mixtures. Agricultural and Food Science in Finland 9: 121-134.

Rinne, M., Nousiainen, J., Mattila, I., Nikander, H. \& Huhtanen, P. 2001. Digestibility estimates based on a grass growth model are distributed via internet to Finnish farmers. Proceedings of the XIX International Grassland Congress, Sao Pedro, Brazil 2001. p. 1072-1073.

Salo, M.-L., Nykänen, A. \& Sormunen, R. 1975. Nurmikasvien koostumus, pepsiini-HCL-liukoisuus ja in vitro-sulavuus eri kasvuasteilla. (Composition, Pepsin-HCL solubility and in vitro digestibility of forages at different growth stages.) Journal of the Scientific Agricultural Society of Finland 47: 480-490. (in Finnish with English abstract).

Sihto, U. \& Rinne, M. 2008. Nurmen kasvumallin kehitys kainuulaisella aineistolla. In: Toim.Anneli Hopponen. Maataloustieteen Päivät 2008,10.-11. 1. 2008. Suomen maataloustieteellisen seuran tiedote 23: 6 p. (in Finnish)

Terry, R.A. \& Tilley, J.M.A. 1964. The digestibility of the leaves and stems of perennial ryegrass, cocksfoot, timothy, tall fescue, lucerne and sainfoin, as measured by an in vitro procedure. Journal of the British Grassland Society 19: 363-372.

Thorvaldsson, G. 1987.The effects of weather on nutritional value of timothy in Northern Sweden. Acta Agriculturae Scandinavica 37: 305-319.

Thorvaldsson, G. 1988. The Morphological and Phenological Development of Timothy as Affected by Weather, and Its Relation to Nutritional Value. Acta Agriculturae Scandinavica 38 (1): 33-48.

Thorvaldsson, G. 2006. Digestibility of timothy. In: Timothy productivity and forage quality - possibilities and limitations. NJF Seminar 384, Akureyri, Iceland, 2006. AUI Publication no. 10: 85-88.

Thorvaldsson, G. \& Andersson, S. 1986. Variations in timothy dry matter yield and nutritional value as affected by harvest date, nitrogen fertilization, year and location in Northern Sweden. Acta Agriculturae Scandinavica 36: 367-385.

Thorvaldsson, G. \& Fagerberg, B. 1988. Effects of weather on nutritional value and phenological development of timothy. Swedish Journal of Agricultural Research 18: $51-59$

Van Soest, P.J., Mertens, D.J. \& Deinum, B. 1978. Preharvest factors inluencing quality of conserved forage. Journal of Animal Science 47: 712-720. 